\title{
Confronting Genocide: Latin America, adventure fiction and the moral crisis of British imperialism
}

\author{
Kevin Foster
}

Adventure fiction was widely employed by British writers during the nineteenth century to address serious questions of politics and morality, particularly those arising from the nation's imperial responsibilities. The nineteenth-century adventure tales that argued for or justified the extension of empire were, in Martin Green's well-worn phrase, 'the energising myth of English imperialism. They were, collectively, the story England told itself as it went to sleep at night, and, in the form of its dreams, they charged England's will with the energy to go out into the world and explore, and conquer and rule. ${ }^{1}$ By the mid nineteenth century, however, some of these adventure narratives, particularly those set in Latin America, were less likely to bring on a reassuring slumber than they were to engender nightmares of self-doubt before waking the sleeper with a nasty start. At a time when the popular literature of empire was slavishly heroworshipping or blindly propagandistic, and high culture all but refused to acknowledge the existence of an imperial frontier, adventure fiction set in Latin America furnished a unique critical and intellectual space within which the political, social and moral consequences of empire might be thought through or imaginatively enacted. ${ }^{2}$

This employment of Latin America in nineteenth and early twentieth-century British adventure fiction grows out of a long-established pattern of discursive relations between the two. J. H. Elliott identifies its precedents in the earliest European responses to the New World. Surveying a wide array of texts from the late sixteenth into the seventeenth centuries, Elliott observes:

[I]t is difficult not to be impressed by the strange lacunae and the resounding silences in many places where references to the New World could reasonably be expected. How are we to explain the absence of any mention of the New World in so many memoirs and chronicles, including the memoirs of Charles $\mathrm{V}$ himself? How are we to explain the

1 Green, M. 1979, Dreams of Adventure, Deeds of Empire, Routledge and Kegan Paul, London, p. 3.

2 Green refers to a 'literature of promotion' stretching 'from the poems of Marston and Chapman to the Twentieth-century pamphlets of the Canada Office in London', whose centrepiece was the work of imperial mythopoeists such as Scott (ibid., p. 119). 
continuing determination, right up to the last two or three decades of the sixteenth century, to describe the world as if it were still the world as known to Strabo, Ptolemy and Pomponius Mela...

The reluctance of cosmographers or social philosophers to incorporate into their work the new information made available to them by the discovery of America provides an example of the wider problem arising from the revelation of the New World to the Old. Whether it is a question of the geography of America, its flora and fauna, or the nature of its inhabitants, the same kind of pattern seems constantly to recur in the European response. It is as if, at a certain point, the mental shutters came down; as if, with so much to see and absorb and understand, the effort suddenly becomes too much for them, and Europeans retreat to the half-light of their traditional mental world.

There is nothing very novel about the form of this sixteenth century response. Medieval Europe had found it supremely difficult to comprehend and come to terms with the phenomenon of Islam... Nor is this a matter for surprise for the attempt of one society to comprehend another inevitably forces it to reappraise itself...This process is bound to be an agonizing one, involving the jettisoning of many traditional preconceptions and inherited ideas. It is hardly surprising, then, if sixteenth-century Europeans either ignored the challenge or baulked at the attempt. There was, after all, an easier way out, neatly epitomized in 1528 by the Spanish humanist, Hernán Perez de Oliva, when he wrote that Columbus set out on his second voyage 'to unite the world and give to those strange lands the form of our own'. ${ }^{3}$

Elliott's vision of sixteenth-century Europeans dazzled by the prodigality of the New World, retreating to 'the half-light of their traditional mental world' from where they seek to understand 'those strange lands' by imposing on them 'the form of our own', furnishes a key image for the processes determining Britain's cultural relations with Latin America and the persistence of its seemingly perennial ignorance about the continent. The British, as Alan Knight observes, have a long and venerable 'tradition of denigrating Latin America and its inhabitants' ${ }^{4}$ In 1850, Palmerston grouped South America with China and Portugal as

3 Elliott, J. H. 1970, The Old World and the New 1492-1650, Cambridge University Press, Cambridge, pp. 13-15. For more on this, see Pastor, B. 1992, The Armature of Conquest: Spanish accounts of the discovery of America, 1492-1589, Stanford University Press, Calif.

4 Knight, A. 1994, Latin America: What price the past? An inaugural lecture delivered before the University of Oxford on 18 November 1993, Clarendon Press, Oxford, p. 3. 
half-civilised governments...[that] require a dressing down every eight or ten years to keep them in order. Their minds are too shallow to receive any impression that will last longer than some such period and warning is of little use. They care little for words and they must not only see the stick but actually feel it on their shoulders before they yield to that argument that brings conviction. ${ }^{5}$

That Palmerston should have harboured such opinions is no surprise when one examines the public and private pronouncements of the diplomats who served in Latin America and whose reports crucially shaped British perceptions of the continent. Sir Robert Ker Porter, the British Consul General in Caracas in the 1820s, found its populace 'ignorant, lazy and full of vice...the manners and usages of the people resemble truly the general appearance of their city...fair remains...choaked [sic] up...with rank weeds' ${ }^{6}$ Charles Milner Ricketts, the British Consul in Lima during the same period, thought the Peruvian Indians 'amiable enough but uneducated, slavish, feeble and inert and moreover hopelessly "priest-ridden"'. ${ }^{7}$ Though neatly dismissed by Alan Knight as the usual round of 'smells, bells and lazy natives', these stereotypes survived well into the twentieth century and are still widespread. ${ }^{8}$ When, between the wars, W. Osbaldeston Mitford left London to take up a diplomatic posting in Mexico City, the members of his London Club - well-travelled men whom he considered 'of a high standard of general education and tolerably well informed on world affairs' - warned him that 'if you ever venture outside the capital you will be made to occupy a cannibal's stewpot or be sacrificed on some pagan altar to an Indian God'. ${ }^{9}$ The pomp and panoply of empire might be gone, but the attitudes that characterised and sustained it have turned out to be more enduring, and, as a result, as Knight ruefully reflects, 'the incomprehension and stereotypes remain, even where least expected'. ${ }^{10}$

David Cannadine's Ornamentalism (2001) helps to further explain the persistence of the intellectual half-light that spawns such stereotypes. It is Cannadine's aim in Ornamentalism to correct the approach of British and foreign scholars who had traditionally regarded British imperial history 'as if it were completely separate and distinct from the history of the British nation'. On the contrary, he contends, 'Britain was very much a part of the empire, just as the rest of the empire was

5 Miller, R. 1993, Britain and Latin America in the Nineteenth and Twentieth Centuries, Longmans, Harlow, Essex, p. 51. See also Pagden, A. 1995, Lords of All the World: Ideologies of empire in Spain, Britain and France c. 1500-1800, Yale University Press, New Haven, Conn.

6 Gregory, D. 1992, Brute New World: The rediscovery of Latin America in the early nineteenth century, British Academic Press, London, p. 130.

7 Ibid., p. 75.

8 Knight, Latin America, p. 3. Cilauro, S., Gleisner, T. and Sitch, R. 2006, San Sombrèro: A land of carnivals, cocktails and coups, Hardie Grant, Prahran, Vic., offers a fine example of the survival of such views.

9 Quoted in Knight, Latin America, p. 5.

10 Ibid., p. 5. 
very much part of Britain', the two comprising an 'entire interactive system' one 'vast interconnected world'. ${ }^{11}$ Indeed, Cannadine argues that the Empire was literally inconceivable in isolation from the metropolitan centre, in that the domestic environment furnished a model by which the broader populace might think of and so understand the Empire. What this meant in practical terms for those Britons struggling to 'conceive of these diverse colonies and varied populations beyond the seas' was that they began 'with what they knew-or what they thought they knew - namely, the social structure of their own home country' ${ }^{12}$ Through the heyday of the Empire, from the mid nineteenth century to the end of World War II,

Britons generally conceived of themselves as belonging to an unequal society characterized by a seamless web of layered gradations... which extended in a great chain of being from the monarch at the top to the humblest subject at the bottom....and it was from that starting point that they contemplated and tried to comprehend the distant realms and diverse society of their empire. ${ }^{13}$

As a result, the people's perception of the Empire

was not exclusively (or even preponderantly) concerned with the creation of 'otherness' on the presumption that the imperial periphery was different from, and inferior to, the imperial metropolis: it was at least as much (perhaps more?) concerned with what has recently been called the 'construction of affinities' on the presumption that society on the periphery was the same as, or even on occasions superior to, society in the metropolis. Thus regarded, the British Empire was about the familiar and domestic, as well as the different and the exotic: indeed, it was in large part about the domestication of the exotic - the comprehending and the reordering of the foreign in parallel, analogous, equivalent, resemblant terms. ${ }^{14}$

Consequently, one of the central if unforeseen functions of the Empire was its provision of a powerful 'mechanism for the export, projection and analogisation of domestic social structures and social perceptions' ${ }^{15}$

Cannadine's assertion that the Empire was dedicated to the domestication of the exotic through parallel, analogy and equivalence is, of course, a calculated rebuttal of the theories of Edward Said. Said's reading of the British Empire

11 Cannadine, D. 2001, Ornamentalism: How the British saw their empire, Allen Lane, London, p. xvii.

12 Ibid., pp. 3-4.

13 Ibid., pp. 3-4. For a more detailed discussion of this, see Cannadine, D. 1998, Class in Britain, Penguin, London.

14 Ibid., p. xix.

15 Ibid., p. 10. 
conceived of it as a bureaucratic and discursive system designed to 'other' and thereby legitimate the oppression of its subject peoples. ${ }^{16}$ Cannadine contends that this approach is 'too simplified', and he is not alone in his recognition that for all his moral forcefulness - if not because of it - Said's understanding of the relations between coloniser and colonised wanted subtlety, that it was unable to acknowledge 'the extent to which empire was about collaboration and consensus as well as about conflict and coercion' ${ }^{17}$ Where the British Empire was concerned, the imperative to analogisation rescued the nation's vision of its far-flung possessions from trite reductivism, producing a sophisticated understanding of its structural complexities and a genuine responsiveness to the lives of the individuals who constituted it. Yet when this same sensemaking system was applied to British visions of Latin America it rendered a disappointing array of familiar stereotypes. ${ }^{18}$ Where one promoted knowledge through identification, the other seemed to foster only ignorance. Why was it that an identical process resulted in such contrasting outcomes?

One explanation resides in the cognitive processes involved in making sense of the unfamiliar. If 'acts of perception are really acts of recall' then what the British saw in India, Africa, Latin America and elsewhere was crucially determined by what they remembered of or had read or heard about equivalent prior experience and the preconceptions they fed. ${ }^{19}$ The effort to understand new experiences, to absorb and evaluate unfamiliar situations involves a combination of what cognitive scientists term 'bottom-up' and 'top-down' processing. Bottom-up processing involves 'building up a composite meaning on the basis of our perception of its component parts'; top-down processing, as its name implies, draws on the 'expectations, assumptions and prior knowledge' of the interpreter. ${ }^{20}$ While regular contact between Britain and its colonies

16 See Said, E. 1978, Orientalism: Western conceptions of the Orient, Penguin, London; Said, E. 1978, The World, the Text, and the Critic, Harvard University Press, Cambridge, Mass.

17 Cannadine, Ornamentalism, p. xiv. Homi Bhabha criticised Said's promotion of a static model of colonial relations in which 'colonial power and discourse is possessed entirely by the coloniser', and in which there is no room for negotiation, compromise or change: Bhabha, H. 1983, 'Difference, discrimination, and the discourse of colonialism', in F. Barker, P. Hulme, M. Iversen and D. Loxley (eds), The Politics of Theory, University of Essex Press, Colchester, p. 200. Leila Ahmed claims that Said offers a homogenised representation of 'the West', while D. Porter asserts that Said's reduction of East-West relations to an entrenched system of binaries overlooks the nuances in their shifting relations over a vast historical stretch: Ahmed, L. 1992, Women and Gender in Islam: Historical roots of a modern debate, Yale University Press, New Haven, Conn.; Porter, D. 1983, 'Orientalism and its problems', in F. Barker, P. Hulme, M. Iversen and D. Loxley (eds), The Politics of Theory, University of Essex Press, Colchester. Dutton and Williams analyse how Said's arguments might be applied to non-Western populations and cultures: Dutton, M. and Williams, P. 1993, 'Translating theories: Edward Said on Orientalism, imperialism and alterity', Southern Review, vol. 26, no. 3, pp. 314-57. Ania Loomba offers a synopsis of these debates in Loomba, A. 1998, Colonialism/Postcolonialism, Routledge, London.

18 Hence Alan Knight's longing for a 'New World equivalent of Edward Said's “Orientalism"' (Knight, Latin America, p. 2).

19 Bartlett, F. C. 1972, Remembering: A study in experimental and social psychology, Cambridge University Press, Cambridge, p. 14.

20 MacLachlan, G. and Reid, I. 1994, Framing and Interpretation, Melbourne University Press, Carlton, Vic., p. 70 . 
served to demystify many of the Empire's exoticisms, to convert a raft of topdown assumptions into the embodied evidence of bottom-up observation, ongoing ignorance about Latin America necessitated a primary - and thereafter habitual-recourse to top-down processes, within which experience and observation might be ordered and explained. Britain's popular imagining of South America, like 'Darkest Africa', might have had its origins in geographical ignorance, but as Philip Curtin remarks, it was subsequently 'adhered to out of cultural arrogance'.$^{21}$

Elliott observes that a society engaged in a genuine effort to comprehend another must undergo an often agonising self-appraisal in which many 'traditional preconceptions and inherited ideas' have to be jettisoned. ${ }^{22}$ This is not a process that any community will undertake lightly, and when it does take place it is driven not by altruism or a disinterested desire for greater knowledge of others but by a combination of compulsion and self-interest. In the case of the Spanish conquest of Latin America,

it was the stimulus of practical considerations - the need to exploit the resources of America and to govern and convert its peoples - which compelled Europeans to widen their field of vision (sometimes in spite of themselves) and to organize and classify their findings within a coherent frame of thought.

Officials and missionaries alike found that, to do their work effectively, they needed some understanding of the customs and traditions of the peoples entrusted to their charge... The visitas of royal officials to Indian localities therefore tended to turn into elaborate inquiries into native history, land tenure and inheritance laws; and the reports of the more intelligent and inquiring of these officials...were in effect exercises in applied anthropology, capable of yielding a vast amount of information about native customs and societies. ${ }^{23}$

The eagerness of the British to conquer and then exploit their imperial possessions, particularly in India, gave rise to practical considerations of government, commerce and comparative religion comparable with those that the Spaniards had confronted in the New World and that, albeit involuntarily, enforced a corresponding extension of the conquerors' cognitive boundaries. ${ }^{24}$

\footnotetext{
21 Curtin, P. 1964, The Image of Africa: British ideas and action, 1780-1850, Macmillan, London, p. 293.

22 As Peter Winch noted: 'Seriously to study another way of life is necessarily to seek to extend our ownnot simply to bring the other way within the already existing boundaries of our own because the point about the latter in their present form, is that they ex hypothesi exclude the other.' Winch, P. 1967, 'Understanding a primitive society', in D. Z. Phillips (ed.), Religion and Understanding, Oxford University Press, Oxford, p. 30. 23 Elliott, Old World, pp. 32-3.

24 David Cannadine advances the case for India's contribution to the making of Britain in Cannadine, Ornamentalism. For Latin America's role in the invention of Europe, see Pratt, M. L. 1992, Imperial Eyes:
} 
Yet in Latin America, while the British had extensive resources to exploit, they had, beyond the thinly scattered populations of Guyana and Belize, no people to govern and so no need to pretend to an interest in or concern for the locals and their cultures, or any mission beyond the extraction of profits or the exercise of influence. They were, as William Yale put it, at liberty 'to secure [their] imperial interests without assuming the invidious burden of colonial rule' ${ }^{25}$ Freed from most of the 'practical considerations' that might demand an uncomfortable cohabitation with the other, the British had no need to expand their settled patterns of thought and perception to make room for the challenges posed by contact with Latin America or its people, and so no reason to subject themselves to a painful process of reappraisal. While Latin America remained of largely commercial interest to the British, their established perceptions of it and the prejudices they fed could survive undisturbed, and the vision of Britain they reflected remain untarnished.

This suggestion that these stereotypical constructions reveal as much about Britain as they do about Latin America implies a further explanation for their persistence. They survive because they continue to perform a valuable function: they express the nation's 'political unconscious'. According to Frederic Jameson, it is the purpose of the political unconscious to restore 'to the surface of the text the repressed and buried reality of [the nation's] fundamental history' ${ }^{26}$ British stereotypes of Latin America restore to the surface of the narratives that preserve them voices previously unacknowledged in or consciously excised from the nation's fundamental history. These voices are significant because instead of extolling the glories of the Empire they have articulated the anxieties inherent in its extension, management and loss. The consolidation and further expansion of the British Empire in the early nineteenth century coincided with the rapid expansion of the revolutionary liberation movements of the Latin American republics. As the British were coming to terms with the moral and practical dilemmas arising from the extension of their dominion across the globe, the peoples of Latin America were, with varying degrees of success, throwing off the yoke of colonial government and for the first time enjoying the rights of free men. As a result, at that point and perennially thereafter in the world of British literary culture (and far beyond), Latin America became inextricably intertwined with a range of efforts to understand and mediate the burdens of

Travel writing and transculturation, Routledge, New York, pp. 172-97.

25 Quoted in Buchan, J. 2003, “"Bitter legacy”, review of Sowing the Wind: The seeds of conflict in the Middle East, by John Keay', Guardian Weekly, 3-9 July 2003, p. 14. Patrick Brantlinger observes that 'Palmerston and many of his contemporaries believed that British overseas interests should be secured whenever possible without formal imperialization': Brantlinger, P. 1988, Rule of Darkness: British literature and imperialism, 1830-1914, Cornell University Press, Ithaca, NY, p. 20.

26 Jameson, F. 1981, The Political Unconscious: Narrative as a socially symbolic act, Routledge, London, p. 20. 
empire. ${ }^{27}$ Narratives set in or centred on Latin America ostensibly concerned with the experience of imperial subjugation can thus be seen as endeavours to address the effects of the exercise of imperial power. Patrick Brantlinger notes that while '[e]mpire involved military conquest and rapacious economic exploitation', it was also characterised by 'the enactment of often idealistic although nonetheless authoritarian schemes of cultural domination. The goal of imperialist discourse is always to weld these seeming opposites together or to disguise their contradiction.' ${ }^{28}$ Latin America furnished an ideal symbolic space, free from the complications of 'official' rule, within which narrative fiction might unpack and illuminate the contradictions of imperialist discourse. Here the 'buried reality' of imperial affirmation could be exhumed and held up for examination. Here the anxieties of the Empire might be articulated, assuaged or indulged. In few places was this more persistently done than in British adventure fiction.

Though Patrick Brantlinger has claimed that in Britain serious 'social doubt' about the aims and morality of imperialism 'emerges in many ways from the 1870s onward', adventure fiction set in Latin America reveals that 'defensiveness, self-doubt, worries about "fitness", "national efficiency" and racial and cultural decadence' do not suddenly and unexpectedly surface at 'the end of the century', but are a consistent presence in the fictional treatment of imperialism from the mid nineteenth century onwards. ${ }^{29}$ They arise from a fundamental contradiction at the heart of the nation's imperial vision residing in the fact that despite the position espoused by 'Palmerston and many of his contemporaries' that 'British overseas interests should be secured wherever possible without formal imperialization', the mid nineteenth century witnessed an exponential growth in the nation's overseas possessions. ${ }^{30}$ Edward Said calculates that while European powers were 'in occupation of approximately 35 percent of the earth's surface' in 1815, by the end of the Great War this had more than doubled to 85 per cent, and a significant proportion of this territory was in British hands. ${ }^{31}$ As such, while explicitly denying an interest in extending its imperial holdings, Britain continued to conquer, dispossess, expropriate and exterminate. Adventure fiction set in non-imperial regions such as Latin America provided a space within which this lust for possession might be balanced against the nation's no less prominent ambivalence about conquest and control. After all, in a place where, as Lord John Roxton remarks in Conan Doyle's The Lost World (2001), 'anythin' was possible - anythin', little was likely to be probable so

\footnotetext{
27 Mediation, Jameson notes, 'aims to demonstrate what is not evident in the appearance of things but rather in their underlying reality' (ibid., p. 39). One of the key texts in this association originated in Argentina: Sarmiento, D. F. 1845, Facundo or Civilization and Barbarism, Penguin, London.

28 Brantlinger, Rule of Darkness, p. 34.

29 Ibid., p. 33. For more detail, see ibid., pp. 19-45.

30 Ibid., p. 20.

31 Said, The World, the Text, and the Critic, p. 222.
} 
anything might be imagined. ${ }^{32}$ The moral and critical licence that freedom from formal political ties to the continent granted enabled the writers of adventure fiction set in Latin America to do three specific things in their work: to reveal, or at least hint at, the unpalatable truths about the nation's conduct on its imperial frontiers; to explore what this conduct implied about the wellbeing of the imperial centre; and to express anxiety or ambivalence about the moral defensibility and practical sustainability of the imperial enterprise as a whole. Latin America thus furnished British writers of adventure fiction with a secure intellectual and political space within which they might pronounce upon the most explosive issue of the day: the moral and political economy of imperialism.

While earlier in the nineteenth century writers such as Robert Southey and Charles Kingsley had fretted over the errant ways of the ruling classes and their continuing fitness for imperial captaincy, as the century reached its close there was a more pointed interrogation not of the nation's capacity to rule, but of the genocidal consequences of its doing so. One of the principal contributions to this debate was Arthur Conan Doyle's The Lost World. By the time of Conan Doyle's birth in 1859, 'the conviction that "inferior peoples" were by nature condemned to extinction' was, as Sven Lindqvist has shown, 'a major element in the European view of mankind'. ${ }^{33}$ Prominent thinkers in biology, anthropology, race and evolutionary theory had separately concluded that the extermination of primitive peoples by their more civilised brethren was the expression of an irresistible law of nature. 'It seemed obvious', from the fact that white men all over the globe were decimating the darker-skinned peoples they came into contact with, 'that some racial natural law was at work and that the extermination of non-Europeans was simply a stage in the natural development of the world' ${ }^{34}$ If by the mid nineteenth century genocide was regarded as an 'inevitable by-product of progress', the key question for modern man was not whether to condone or condemn it, but how to arrive at some sort of moral accommodation with it. ${ }^{35}$ It was the moral responsibility of civilised man not to protest against the eradication of primitive peoples, but to ensure that they were taken off in the most efficient and humane fashion. Restraint or mercy in this context, Eduard von Hartmann argued, was not charity, but a species of cruelty:

As little as a favour is done the dog whose tail is to be cut off, when one cuts it off gradually inch by inch, so little is there humanity in artificially prolonging the death struggles of savages who are on the

32 Conan Doyle, A. [1912] 2001, The Lost World and Other Thrilling Tales, Penguin, London, p. 61.

33 Lindqvist, S. 1997, 'Exterminate All The Brutes', Granta, London, p. 10.

34 Ibid., p. 115.

35 Ibid., p. 123. 
verge of extinction... The true philanthropist, if he has comprehended the natural law of anthropological evolution, cannot avoid desiring an acceleration of the last convulsion and labour for that end. ${ }^{36}$

As early as 1850, Herbert Spencer had proposed that the eradication of the unregenerate was not a matter for moral vacillation, but a binding religious obligation: 'The forces which are working out the great scheme of perfect happiness, taking no account of incidental suffering, exterminate such sections of mankind as stand in their way... Be he human or be he brute - the hindrance must be got rid of.' ${ }^{37}$ In this context, instead of wringing their hands over the plight of the unfortunate victims, it was believed that 'the true compassion of the superior races consisted in helping them on their way' ${ }^{38}$

Not everybody was convinced that the extinction of primitive peoples was inevitable, or regarded genocide as a misunderstood species of Christian charity. Surveying the catastrophic results of modern man's endeavours to improve his primitive brothers, John Howison argued that the real savages were closer to home, and that it was civilised man himself who was most in need of moral reform:

The continent of America has already been nearly depopulated of its aborigines by the introduction of the blessings of civilisation. The West Indian archipelago, from the same cause, no longer contains a single family of its primitive inhabitants. South Africa will soon be in a similar condition, and the islanders of the Pacific Ocean are rapidly diminishing in numbers from the ravages of European diseases and the despotism of self-interested and fanatical missionaries. It is surely time that the work of destruction should cease; and since long and melancholy experience has proved us to be invariably unsuccessful in rendering happier, wiser, or better, the barbarians whom we have visited or conquered, we may now conscientiously let them alone and turn a correcting hand towards ourselves and seek to repress...our avarice, our selfishness, and our vices. ${ }^{39}$

In The Lost World, Conan Doyle strips away the lagging of respectability that science and religion had afforded genocide, exposing the ugly truths about colonial dispossession, and exploring thereby Howison's theories about the

36 Von Hartmann, E. [1884] 1970, Philosophy of the Unconscious: Speculative results according to the inductive method of physical science, Basic Books, New York, p. 12.

37 Spencer, H. 1850, Social Statistics, or The Conditions Essential to Human Happiness Specified, and the First of them Developed, John Chapman, London, p. 461.

38 Lindqvist, 'Exterminate All The Brutes', p. 123.

39 Quoted in ibid., p. 122. After an inquiry into the extermination of the Tasmanian Aborigines, the Aborigines' Protection Society was founded in 1838 'with the aim of putting an end to the extermination of native peoples' (ibid., p. 124). 
complicated relations between civilisation and savagery. Conan Doyle projects his analysis of the practical implications and moral burdens of empire onto an imaginary Latin American landscape. Here, in the semiotic free-fire zone that this setting affords, and in the sort of detail that no account of Britain's imperial front line could countenance at the time, he illustrates what happens when civilised man finds his pursuit of land, loot or security obstructed by his more primitive brothers, and how he justifies and lives with the bloody consequences of his actions. As such, his central concern in The Lost World is to offer an allegorical critique of the moral landscape of British imperialism, to use Latin America to explore and explain a society in which obscure matters of scientific dispute occasion outrage and wild public brawling, while the eradication of whole peoples passes without comment.

The fictional premise that underpins this analysis rests on maverick Professor George Edward Challenger's discovery of an isolated plateau in Brazil, where, cut off from the evolutionary conditions that have shaped the modern world, ancient life forms coexist with more developed species. When Challenger presents these findings to a meeting of the Zoological Institute in London, they provoke uproar. Undaunted, he invites the institute to dispatch a party to the area to test the veracity of his claims. This group - comprising a professor of comparative anatomy, Summerlee, the gentleman adventurer, Lord John Roxton, and the journalist and narrator, Edward Malone - is duly elected, dispatched, and later augmented in the upper reaches of the Amazon by Challenger himself. The party heads inland, locates and ascends the plateau, and the adventure begins. For all the primeval glamour of this lost world, its soupy central lake bubbling with amphibious proto-life, antlered herds, swooping pterodactyls, and the lumbering Jurassic bestiary, the narrative centres on the struggle for dominion between the plateau's competing hominid groups: the 'ape-men', who are primitive, simian and savage, and the more evolved Indians-'small men, wiry, active...Their faces...hairless, well-formed and good humoured' ${ }^{40}$ Despite their evolutionary advantages, the Indians are barely holding their own against the depredations of the ape-men and when the adventurers encounter them are fighting for their survival. The opposing groups' differing conduct of the struggle implies a good deal about each. If violence is, for the Indians, an unpalatable means to the higher end of peace and progress, for the ape-men the slaughter of their enemies is an entertaining end in itself. The ceremonial centrepiece of their society is a bizarre and entirely purposeless sacrificial rite in which, to the ape-men's evident delight, the hapless victim is flung off

40 Conan Doyle, The Lost World and Other Thrilling Tales, pp. 151, 153. For a description of the ape-men, see ibid., p. 130. For more on their status as the 'missing links', see Fraser, R. 1998, Victorian Quest Romance: Stevenson, Haggard, Kipling, and Conan Doyle, Northcote House, Plymouth, UK, pp. 70-4. 
the plateau to his death far below. ${ }^{41}$ When the adventurers are attacked and brutalised by the ape-men, they take an active role in the conflict and play midwife to evolution. Contributing their more advanced military strategy and greater force of arms to the Indians, in a final, climactic confrontation, they help them defeat and all but exterminate the ape-men. Fresh from the massacre, Challenger observes that it has been their privilege

to be present at one of the typical decisive battles of history - the battles which have determined the fate of the world. What, my friends, is the conquest of one nation by another? It is meaningless. Each produces the same result. But those fierce fights, when in the dawn of the ages the cave-dwellers held their own against the tiger folk, or the elephants first found that they had a master, those were the real conquests - the victories that count. By this strange turn of fate we have seen and helped to decide even such a contest. Now upon this plateau the future must ever be for man. ${ }^{42}$

Yet for all his evocation of the historical moment, Challenger's orthodox vindication of the evolutionary process does nothing to mitigate the horrors at its sharp end. As Malone notes:

It needed a robust faith in the end to justify such tragic means. As we advanced together through the woods we found the ape-men lying thick, transfixed with spears or arrows...driven back to their city, they had made a last stand there, once again they had been broken, and now we were in time to see the final fearful scene of all... As we arrived the Indians, a semi-circle of spearmen, had closed in on them, and in a minute it was over. Thirty or forty died where they stood. The others, screaming and clawing, were thrust over the precipice, and went hurtling down, as their prisoners had of old, on to the sharp bamboos six hundred feet below. ${ }^{43}$

The particular manner in which the last of the ape-men are dispatched is highly suggestive, not least in its biblical allusion to the Gadarene Swine. More pertinently, and more topically, it alludes to a method commonly employed by white settlers in Australia to dispose of Aborigines with whom they were in conflict over land or natural resources. ${ }^{44}$ Further, the strange clicking talk of the

\footnotetext{
41 For Roxton's description of the ceremony, see Conan Doyle, The Lost World and Other Thrilling Tales, p. 154.

42 Ibid., p. 174. Challenger refers here to the Victorian bestseller The Fifteen Decisive Battles of the World, by Edward Creasy ([1852] 1962, Dent, London). I am indebted to Dr Robert Dingley for pointing this out.

43 Conan Doyle, The Lost World and Other Thrilling Tales, p. 174.

44 For more details, see Schlunke, K. M. 2005, Bluff Rock: Autobiography of a massacre, Curtin University Books, Fremantle, WA; Elder, B. 1988, Blood on the Wattle: Massacres and maltreatment of Australian Aborigines since 1788, National Book Distributors and Publishers, Frenchs Forest, NSW.
} 
ape-men recalls the languages of the Nama and Herero people of South-West Africa, now Namibia, who after rebelling against the cruelty of the colonising Germans were almost entirely exterminated in 12 months during 1904-05. ${ }^{45}$ These parallels drive home Conan Doyle's point that though the superior beings might claim to be accidental witnesses to the working out of a natural law, here and all across the globe, they have shown themselves to be active, if not enthusiastic, participants in the extermination of their fellow men.

Furthermore, their responses to or reasons for participating in the slaughter suggest that they are not nearly as civilised as they believe themselves to be. Challenger might portray himself as no more than a fortunate witness to an irresistible natural process, but when Malone and Roxton come across him in the final stages of the massacre of the ape-men, he has abandoned all pretence to scientific detachment and is 'strutting about like a gamecock', his eyes 'shining with the lust of slaughter' ${ }^{46}$ If Challenger's regressive savagery comes as a shock, Lord John Roxton's coldly rational determination to settle a personal 'score' with the ape-men by 'wiping them off the face of the earth' is more deeply alarming. The ape-men's sin? The 'filthy beasts' had 'fingered [him]... all over' ${ }^{47}$ Increased refinement, Conan Doyle demonstrates, brings not a transcendence of savagery, merely a greater facility in justifying or excusing its employment. In their efforts to demonstrate their superiority over the brutal primitives of the plateau, the adventurers only reinforce the evidence of their commonality with them. The ape-men's sacrificial rites might revolt Roxton but they also fascinate him: 'It was horrible - but it was doocedly interestin' too.' ${ }^{48}$ When Malone fires on the ape-men he is less the well-drilled territorial marksman than a blood-crazed berserker, 'cheering and yelling with pure ferocity and joy of slaughter' ${ }^{49}$

Yet as Conan Doyle points out, in this regard there is nothing extraordinary about the members of the party. By turns suave, savage and coldly scientific, the adventurers are fitting emblems of their society and the brutality that bristles beneath its civilised exterior. 'There are', Malone reflects, 'strange red depths in the soul of the most commonplace man'.$^{50}$ Indeed the behaviour of London's intellectual elite is at times scarcely distinguishable from the pack frenzy of the ape-men. Conan Doyle lavishes considerable detail on the two Zoological Institute lectures that bookend the party's journey to South America, and how each descends into wild brawling. He notes how, during the first lecture, the

45 For the clicking language, see Conan Doyle, The Lost World and Other Thrilling Tales, pp. 152, 156. For the German massacre of the Herero, see Cocker, M. 2001, Rivers of Blood, Rivers of Gold: Europe's conquest of indigenous peoples, Grove Press, New York, pp. 269-371.

46 Conan Doyle, The Lost World and Other Thrilling Tales, p. 174.

47 Ibid., pp. 153, 170.

48 Ibid., p. 154.

49 Ibid., p. 159.

50 Ibid., p. 159. 
roar of the audience was 'a frightful outburst of sound', less like the expression of reasoned debate than 'the uproar of the carnivora cage when the step of the bucket-bearing keeper is heard in the distance'. ${ }^{51}$ The second meeting is preceded by 'a prolonged melee in which several people were injured' ${ }^{52}$

The key figure linking the seemingly antithetical extremes of civilisation in the novel is the 'splenetic scientist', Challenger. ${ }^{53}$ His formidable intellect is strangely yoked to a pathological incapacity to restrain himself; he is forever 'effervescing with fight' ${ }^{54}$ In a manner later made famous by Monty Python's wrestling bishops, he meets scepticism, or any expression of intellectual difference, with an immediate recourse to physical assault. When, after his attack on Malone, his exasperated wife describes him as 'a brute', this is no idle rhetorical figure. ${ }^{55}$ Every description of Challenger emphasises his squat, simian bulk: he is 'a stunted Hercules whose tremendous vitality had all run to depth, breadth and brain' ${ }^{56}$ His affinity with the ape-men is first implied in a glint of teeth. Immediately before he launches an assault on Malone, his 'black moustache lifted and a white fang twinkled in a sneer' ${ }^{57}$ This brief glimpse of Challenger's fangs and the bestial instinct they signify have an important echo later in the novel, when Malone is throttled by an ape-man. Drifting into unconsciousness, he recalls that as 'the creature felt me grow limp in his grasp, two white canines gleamed for a moment at each side of the vile mouth' ${ }^{58}$ Little wonder that when the adventurers are captured by the ape-men, while Summerlee and Roxton are humiliated and brutalised, in Challenger they recognise and revere a more advanced specimen of their own kind, bearing him aloft like 'a Roman emperor' ${ }^{59}$ The uncanny likeness between the scientific übermann and the degenerate apes makes explicit what is only hinted at in Challenger's volcanic temper and Malone's berserker frenzy: that for all the smug assurance of his evolutionary advantages, modern man has not left his more primitive self behind but carries his primordial savagery within him, and the least provocation might bring it to the surface and betray him. This insistence on the fellowship between civilised man and his primitive forebears demolishes the orthodox scientific and moral vindications of genocide, exposing the uncomfortable truth that for all its cant about civilisation, progress and mission, colonialism involved the dispossession and destruction of men, who, whatever their physical or cultural differences, were inescapably our kith and kin, if not our brothers.

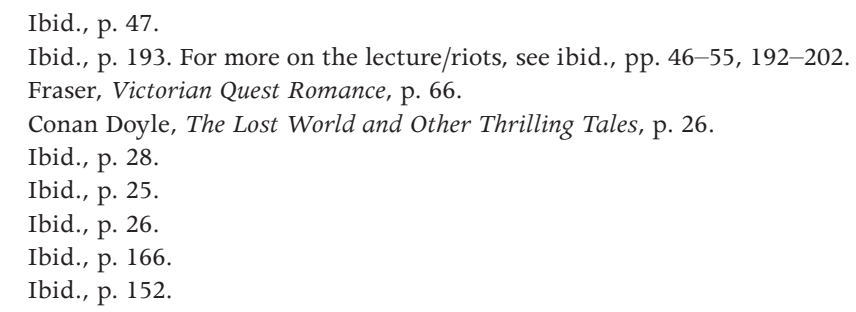


Conan Doyle's moral point here has an important political dimension. Having rescued a number of Indians from certain death at the hands of the apemen, Challenger is gratified by the grovelling obeisance they display towards the adventurers: 'They may be undeveloped types', he observes, 'but their deportment in the presence of their superiors might be a lesson to some of our more advanced Europeans' ${ }^{60}$ Challenger's remarks point up the degree of anxiety among the British about a perceived falling off in the deference that they felt was due to them from their European competitors. This, in turn, resulted from a relative decline in Britain's power and prestige in the decade before World War I. ${ }^{61}$ Conan Doyle's message is clear. If the British wish to retain their pre-eminence, if they are not to find themselves at the sharp end of political and military evolution and wish to avoid the fate of the ape-men, they will have to draw on all of their instinctual resources to compete against and conquer their competitors, to fight harder than ever before to prove their superior civilisation. Barbarians, Conan Doyle points out, are not to be regarded as 'objects of disgust... but as the models of a new imperial masculinity' ${ }^{62}$ As Jacqueline Jaffe noted: 'Only by learning to be more like Challenger can they hope to ensure their continuance. ${ }^{63}$ Genocide, in this context, is less a moral issue than an arresting reminder of the contingent nature of national superiority, and a demonstration of what, in different, more hostile circumstances, their fate might yet be. The novel thus condemns the brutality of the colonial frontier while conceding its indispensable role in ensuring the survival and integrity of the nation. As Jaffe put it:

Doyle is not advocating a return to the bestiality of the ape-men. Rather, he is suggesting that as life in a post industrial, materialistic society has led to a spiritual and moral decline, a salutary look at a time when people had to fight to survive and life was worth fighting for would not come amiss. Challenger, the ape-man/scientist, is a perpetual reminder of qualities that the middle class had forgotten ever existed. ${ }^{64}$

What is most ironic about this muted call for an appreciation of cultural relativism is the manner in which Conan Doyle articulates it by drawing on and reinforcing a range of orthodox visions of Latin America. He grounds his call for cultural understanding in a discursive bedrock of prejudice and received opinion. Though at the outset of the novel Malone's editor laments that the 'big blank spaces on the map are all being filled in, and there's no room for romance

\footnotetext{
60 Ibid., p. 169.

61 Modris Ecksteins discusses the decline in Britain's status at this juncture in Ecksteins, M. 1989, Rites of Spring: The Great War and the birth of the modern age, Black Swan, London, pp. 105-8.

62 Deane, B. 2008, 'Imperial barbarians: primitive masculinity in lost world fiction', Victorian Literature and Culture, vol. 36, p. 207.

63 Jaffe, J. A. 1998, Arthur Conan Doyle, G. K. Hall and Co., Boston, p. 98.

64 Ibid., p. 97.
} 
anywhere', the succeeding action demonstrates that where Latin America is concerned quite the contrary is the case. ${ }^{65}$ If elsewhere in the world the routine processes of discovery, exploration, mapping and settlement are held to be inimical to romance, in Latin America the reverse is in force. As Roxton points out to Malone, the more one fills in the blank spaces on the map of Latin America, the more one multiplies both the opportunities and the appetite for adventure: 'if you take it right through from Darien to Fuego, it's the grandest, richest, most wonderful bit of earth upon the planet... The more you know of that country, young fellah, the more you would understand that anythin' was possible - anythin'.'66 Anything might be possible, but what actually happens in Latin America is inevitable. The novel might pose some awkward questions about colonialism, but as a model of narrative imperialism it is hard to beat.

Conan Doyle's Latin America is imagined and constructed purely as a means of addressing and resolving what were, for the British, determinedly domestic anxieties. As the British grappled with the moral, political and social burdens of imperialism, Conan Doyle employed Latin America to imagine the nation's darkest fears, rehearse its guiltiest secrets, and exorcise its most shameful fantasies - to play out a final solution for the primitive peoples of the world. What the British most feared and desired-absolute power, what they could do with it, and what might happen to them were they to lose it - is given substance in the personal and political engagements played out on the plateau. While the anxieties that this depiction of Latin America addresses are resolved or shift focus, while the moral and social questions lose their relevance as the world changes, Conan Doyle's portrait of Latin America as a landscape of bold polarities and brutal extremes, of entrenched antagonisms, conquest and subjection, degeneracy and cultivation, beasts and men, remains constant. It is this very constancy that has made it so useful to British writers, and has thus reinforced its stubborn unchangingness. Latin America's reliable failure to develop, its comic petrification, furnishes a handy measure of how others have evolved. For Conan Doyle, the ossification of Latin America, its continual revisiting of irreducible antagonisms and the age-old struggles they breed, are less matters for moral or political condemnation than they are an indispensable, deep structure that enables their differing analyses of and responses to the perilous state of contemporary Britain.

65 Conan Doyle, The Lost World and Other Thrilling Tales, p. 15. In John Buchan's The Courts of the Morning, Archie Roylance confesses that 'he had always had a romance about [South America], and he understood that it was the only place which still held some geographical secrets'. Buchan, J. 1929, The Courts of the Morning, Thomas Nelson and Sons, London, p. 16.

66 Conan Doyle, The Lost World and Other Thrilling Tales, pp. 60-1. 